
\title{
25 Research Sourere \\ In vitro evaluation and molecular docking analysis of potential anticancer compounds from Annona muricata L.
}

Pichai Nalini

PSG College of Arts and Science

Kalibulla Syed Ibrahim

PSG College of Arts and Science

Durairaj Brindha ( $\nabla$ publicationbiochemistray@gmail.com )

PSG College of Arts and Science

\section{Research Article}

Keywords: Annona muricata L., Anticancer, Dalton's Lymphoma Ascites, NAT2, COX2, p53, Molecular Docking

Posted Date: June 2nd, 2021

DOl: https://doi.org/10.21203/rs.3.rs-172301/v1

License: (c) (i) This work is licensed under a Creative Commons Attribution 4.0 International License. Read Full License 


\section{Abstract}

Annona muricata L. is widely distributed in tropical and subtropical regions around the world.

Traditionally this plant has been used as a medicine for multiple ailments including cancer. The present study focussed on the anticancer activities of hydroethanolic extracts of leaves of A. muricata L. on Dalton's Lymphoma Ascites (DLA) cell line in comparison with standard drug doxorubicin. Cytotoxicity studies have indicated that the phytoconstituents of $A$. muricata have the ability to selectively target cancer cells $\left(\mathrm{IC}_{50}=185.585 \mu \mathrm{g} / \mathrm{ml}\right)$, whereas minimal or negligible cytotoxic effects were observed on normal cells. Gas Chromatography - Mass Spectrometry data revealed the presence of 16 phytoconstituents comprising mainly alkaloids and phenolic compounds. Pharmacokinetic profiling and molecular docking studies using the phytoconstituents were performed in order to gain a better understanding of the putative mechanisms of action leading to the development of improved and affordable therapies.

\section{Introduction}

Cancer remains one of the leading causes of preventable death regardless of significant medical and technological advancements in patient prognosis. With the current trend, the International Agency for Research on Cancer (IARC) predicted new cancer cases and death may rise up to $75 \%$ by 2030 (Ferlay et al. 2015). Phytochemical constituents of plants have been helping mankind as medicine with potent therapeutic effects along with minimal side effects. In recent years, phytochemicals have stimulated considerable interest due to a wide range of beneficial biological activities (Moghadamtousi et al. 2015). Annona muricata L. is a plant with extensive traditional use in food and as medicine for their efficacy as a potential candidate for a variety of treatments (Coria-Téllez et al. 2016), including different cancers (Newman and Cragg, 2015).

A. muricata L. belongs to Annonaceae family, comprising 130 genera and 2300 species, commonly known with a variety of names like paw-paw, soursop, graviola, sirsak and guanabana, (Leboeufet al. 1980). A. muricata is an evergreen terrestrial, erect tree, having an open, roundish canopy with large, dark green leaves, glossy in nature (Moghadamtousi et al. 2015). The tree bears green color edible fruits, which are heart-shaped and around 15 to $20 \mathrm{~cm}$ in diameter that varies from country to country (De Souza et al. 2009).

Almost every part (leaves, flowers, fruits, seeds, barks and roots) of $A$. muricata have ethnomedicinal applications and have been extensively evaluated for the presence of various phytoconstituents, majority being acetogenins and alkaloids, while few of these chemical constituents were shown to be exhibiting anticancer properties (Badrie and Schauss, 2009).

A. muricata leaves were reported to be major source of annonaceous acetogenins, which are unique long chain fatty acids containing phytochemical species (C32 or C34) derived from the polyketide pathway in Annonaceae family (Liaw et al. 2016, Sun et al., 2016). Coria-Téllez et al. have reported 212 bioactive 
compounds in A. muricata extracts exhibiting a wide range of anticancer effects in vitro and in vivo (Coria-Téllez et al. 2016).

Based on different mechanistic studies Annonaceous acetogenins (ACGs) were found to exert its effects (i) by inhibiting the mitochondrial complex I of the electron transport chain by down-regulating mitochondrial NADH oxidase function, (McLaughlin 2008); (ii) killing multidrug-resistant cancers by down-regulating and/or modulating drug efflux proteins (Alali et al.1999, Deep et al.2016); (iii) inhibiting cytotoxic cell survival and metastasis by targeting Epidermal Growth Factor Receptor (EGFR) signalling (McLaughlin 2008, Dai et al. 2011, Torres et al.2012); and (iv) inducing endoplasmic reticulum (ERe) stress (Liu et al.2016). The active ACGs have also been shown to successfully induce apoptosis cancer cells that are resistant to chemotherapeutic drugs (Chang et al. 2001). Qazi et al. (2018) have described the putative molecular mechanisms of $A$. muricata as an effective antiproliferatve agent against various cancers. The above studies suggest the strong therapeutic efficacy of $A$. muricata in combating various malignancies. Surprisingly AGEs were also described as environmental neurotoxins accounting for neurodegenerative disorders (Gavamukulya et al., 2017).

Studies have indicated that geographical edaphic factors modulate the phytochemical composition and content besides anticancer efficacies (Syed Najmuddin et al. 2016). Owing to its broad anticancer activities on various cancer cells (Qazi et al. 2018), we decided to perform in vitro assessment of anticancer potential of A. muricata leaf extracts in Dalton's Lymphoma Ascites (DLA) cell line and in addition, in silico investigations were performed to reveal whether BCL2, COX2, NAT2, and p53 enzymes are the preferred molecular targets, for the first time.

\section{Materials And Methods}

\section{Collection and Extraction of Plant Material}

Fresh leaves of $A$. muricata were collected from farmer's field, Pechiparai, Nagercoil and were authenticated by the Head, Botanical Survey of India, in Tamil Nadu Agricultural University, Coimbatore (BSI/SRC/5/23/2015/Tech/153). The leaves were then washed with running water to remove dust and shade dried at room temperature. The dried leaves were ground to fine particles, sieved and stored in sterile air tight container at $4^{\circ} \mathrm{C}$ until further analysis.

\section{Preparation of plant extract}

Approximately $25 \mathrm{~g}$ of the leaf powder was weighed and soaked separately in $250 \mathrm{ml}$ of hydroethanol $(1: 10 \mathrm{w} / \mathrm{v})$. These suspensions were agitated manually to increase extraction efficiency and left undisturbed for $72 \mathrm{~h}$. It was then filtered using Whatmann No.1 Filter paper and subsequently filtrates were dried in vacuo. The hydroethanolic extracts of $A$. muricata (HEEAM) were stored at $4^{\circ} \mathrm{C}$ until further use. 


\section{Determination of the cell viability by MTT assay}

DLA cells aspirated from DLA bearing mice were seeded in a 96-well flat-bottom microtiter plate containing approximately 7000 cells/well and incubated for $24 \mathrm{~h}$ at $37^{\circ} \mathrm{C}$ in the presence of $5 \% \mathrm{CO}_{2}$. Different concentrations of HEEAM were added and incubated at same temperature for further $48 \mathrm{~h}$. Before the completion of incubation (4h), $15 \mu \mathrm{l}$ of MTT $(0.5 \mathrm{mg} / \mathrm{ml})$ in phosphate buffered saline was added. The supernatant was collected and treated with $200 \mu \mathrm{l}$ of DMSO and the absorbance was recorded at $570 \mathrm{~nm}$. The percentage growth inhibition was then calculated according to Hajighasemi and Mirshafiey (2010). Control cells were arbitrarily assigned a value of $100 \%$.

\section{Statistical analysis}

The statistical analysis was performed using oneway ANOVA - Dunnett's test and for all comparisons, differences were considered statistically significant at $P<0.05$. The IC50 value $(50 \%$ inhibitory concentration) of the crude extracts was calculated by plotting inhibition percentage against different extract concentrations.

\section{DNA fragmentation assay}

The isolation of fragmented DNA was carried out according to the procedure of Ding et al. (2009). DLA cells $\left(1^{\prime} 10^{6}\right)$ were seeded in a $10 \mathrm{ml}$ cell culture bottle and treated with HEEAM $(100$ and $200 \mu \mathrm{g} / \mathrm{ml})$ and doxorubicin $(10 \mu \mathrm{g} / \mathrm{ml})$ for $48 \mathrm{~h}$. The untreated (control) as well as treated cells were harvested and washed twice with PBS. The cells were then lysed using $100 \mu \mathrm{l}$ lysis buffer $(10 \mathrm{mmol} / \mathrm{L} \mathrm{Tris-Cl,} 10 \mathrm{mmol} / \mathrm{L}$ EDTA ( $\mathrm{pH} 8.0$ ) and $0.5 \%$ Triton $\mathrm{X}-100)$ at $50^{\circ} \mathrm{C}$ for $2 \mathrm{~h}$. The supernatant were acquired through centrifugation at $1600 \mathrm{~g}$ for $10 \mathrm{~min}$ and incubated with $5 \mu \mathrm{l}$ of RNaseA $(20 \mathrm{mg} / \mathrm{ml})$ at $37^{\circ} \mathrm{C}$ for $60 \mathrm{~min}$. Proteins were removed by incubation with $5 \mu$ l of proteinase $\mathrm{K}(20 \mathrm{mg} / \mathrm{ml})$ at $37^{\circ} \mathrm{C}$ for $60 \mathrm{~min}$. The supernatant were subjected to electrophoresis at $6 \mathrm{~V} / \mathrm{cm}^{2}$ for $3 \mathrm{~h}$ in $2 \%(\mathrm{w} / \mathrm{v})$ agarose gel.

\section{Detection of apoptotic morphological changes by Acridine Orange/Ethidium Bromide dual staining method}

The cytotoxicity induced by apoptosis was confirmed by acridine orange (AO) and ethidium bromide (EB) staining method (Shailaja et al. 2006). DLA cells isolated from DLA bearing mouse was washed with Phosphate-buffered saline (PBS) and $1 \times 10^{6} \mathrm{cell} / \mathrm{s} / \mathrm{ml}$ were treated with $50-200 \mu \mathrm{g} / \mathrm{ml}$ of HEEAM for $20 \mathrm{~h}$ at $37^{\circ} \mathrm{C}$ in the presence of $5 \% \mathrm{CO}_{2}$. After the incubation, cells were washed in PBS, stained with $20 \mu \mathrm{l}$ of ethidium bromide/acridine orange and resuspended in PBS. The images were captured after examining on a slide under a fluorescence microscope.

\section{Gas Chromatography - Mass Spectrometry Analysis}

The volatile component analyses were performed using a GC-MS system (SHIMADZU Model- GC-MS QP 2010 Plus) using $1 \mu \mathrm{l}$ plant extract and helium (99.999\%) as the carrier gas at a flow-rate of 
$1 \mathrm{ml} / \mathrm{min}$. Capillary column Rxi-1 (100\% dimethyl polysiloxane;30 $\mathrm{m} \times 0.25 \mathrm{mmID}, 0.25 \mu \mathrm{m}$ ) was used. The temperature of the injection port was $270^{\circ} \mathrm{C}$, and the column temperature program was as follows: $50^{\circ} \mathrm{C}$ for $2 \mathrm{~min}$, followed by a gradual increase in temperature to $180^{\circ} \mathrm{C}$ at a rate of $5^{\circ} \mathrm{C} / \mathrm{min}$, an increase to $280^{\circ} \mathrm{C}$ at a rate of $20^{\circ} \mathrm{C} / \mathrm{min}$, and maintenance at $280^{\circ} \mathrm{C}$ for $5 \mathrm{~min}$. The MS conditions included an electron impact (EI) ion source temperature of $230^{\circ} \mathrm{C}$, ionization energy of $70 \mathrm{eV}$, and a mass scan range of 40-800 atomic mass unit (amu). The separated constituents' mass spectra were then compared with those in the NIST08 MS library (National Institute of Standards and Technology, Gaithersburg, MD, USA).

\section{Target and ligand preparation}

The protein sequences of B-cell lymphoma 2 (BCL2; P10415), Cyclooxygenase 2 (COX2; P35354), NAcetyltransferase 2 (NAT2;P11245) and TP53 or tumor protein p53 (P04637) were retrieved ExPasYUniProtKB (Gasteiger et al. 2003; Pundir et al. 2017). Their 3D structures were modeled using Swiss-Model (Biasini et al. 2014) web server and used as receptor molecule for the docking study using AutoDock 4.2 (Morris et al. 2009). The structures were refined and energy minimized using ModRefiner (Xu and Zhang 2011) and GROMOS 96 force field (van Gunsteren et al. 1996), respectively. Energy refined models were then validated from Rampage (Lovell et al. 2003) using Ramachandran plot. The structural files of ligands were retrieved in 3D from PubChem database (http://www.pubchem.ncbi.nlm.nih.gov). ADME parameters, pharmacokinetic properties, drug like nature and medicinal chemistry friendliness were predicted using SwissADME (Daina et al. 2017). Doxorubicin was used as the control for the study.

\section{Docking of receptorsand ligands}

Autodock Tools (ADT) was used to prepare the receptor and ligand molecules (Morris et al. 2009). Polar hydrogens, Kollman charges and AD4 type of atoms were added to the receptor molecule, while ligands were added with Gasteiger charges and maximum numbers of active torsions were maintained. AutoGrid was used to prepare a grid map. For COX2 a grid box of $60 \times 60 \times 60$, centered on $X, Y, Z=23.672$, $33.902,60.405$, for $\mathrm{p} 53$ a grid box of $46 \mathrm{X} 50 \mathrm{X} 82$, centered on $X, Y, Z=-9.731,2.097,1.112$, for BCL2 a grid box of $60 \times 60 \times 60$, centered on X, Y, Z =32.613,35.183, 63.533 and for NAT2 a grid box of $60 \times 60$ $X 60$, centered on $X, Y, Z=0.310,44.725,59.118$. A grid spacing of $0.375 \AA$ was maintained for all docking procedures. The choice of the targets and their active sites were as per earlier reports (Wu et al. 2007, Wang et al. 2010). Lamarckian Genetic Algorithm (LGA) was used for performing molecular docking, keeping the receptor molecule rigid throughout the docking simulation. The population size was set to 150 and the individuals were initialized randomly and the maximum number of energy evaluations was set to 500,000 . Rest of the docking parameters was set to default values. Ten different poses were generated for each ligand and scored using AutoDock 4.2 scoring functions and were ranked according to their docked energy. PyMOL (https://www.pymol.org) was used for post docking analysis.

\section{Results And Discussion}

\section{In vitro cytotoxicity}


The cytotoxicity activity of HEEAM was studied against DLA cell lines over a concentration range, viz., 25 $\mu \mathrm{g} / \mathrm{ml}, 50 \mu \mathrm{g} / \mathrm{ml}, 100 \mu \mathrm{g} / \mathrm{ml}, 200 \mu \mathrm{g} / \mathrm{ml}$ and $400 \mu \mathrm{g} / \mathrm{ml}$. The cell viability \% of the HEEAM treated cells at different concentrations is shown in Table 1. The cytotoxic activity of HEEAM was observed at all tested concentrations. Importantly, the higher concentration level of $400 \mu \mathrm{g} / \mathrm{ml} \mathrm{HEEAM} \mathrm{was} \mathrm{more} \mathrm{effective}$ indicative of a dose-dependent cytotoxicity which was significant $(\mathrm{p}<0.05)$. The evaluated inhibitory concentration $\left(\mathrm{IC}_{50}\right)$ of HEEAM was $185.585 \mu \mathrm{g} / \mathrm{ml}$. One-way ANOVA analysis results indicated that there are significant differences in cytotoxicity.

Besides, HEEAM exhibited antiproliferative effect which was evident from the DNA fragmentation assay, when compared to the untreated DLA control. The bands were compared with 200bp DNA marker (Figure 1). There was no clear fragmentation pattern in DLA control group (Lane 2), whereas distinct nuclear fragmentation was detected in HEEAM treated groups (Lane 3 at $200 \mu \mathrm{g} / \mathrm{ml}$ concentrations and Lane 4 at $400 \mu \mathrm{g} / \mathrm{ml}$ concentrations). This result suggested that HEEAM caused considerable nuclear fragmentation at short incubation periods. Lane 5, served as the positive control (doxorubicin). Chromosomal DNA Cleavage (Wyllie 1980), chromatin condensation, nuclear shrinkage, apoptosis body formation and phagocytosis by neighbouring cells and loss of membrane integrity are the major events during the apoptosis process (Kerr et al. 1972). Normally, apoptosis is characterized by an evident chromatin DNA cleavage around 200bp intervals (Oberhammer et al. 1993) whereas, a 'smear' on agarose gel is observed in necrosis owing to random DNA fragmentation (Mizuta et al. 2013).

To investigate the morphological changes induced by HEEAM during apoptosis, cells were stained with $\mathrm{AO} / \mathrm{EtBr}$, which allows the identification of viable, apoptotic, and dead cells by virtue of colour and appearance.DLA cells emitted green fluorescence which is suggested to be the associated with chromatin condensation and nuclear fragmentation (Figure 2). The HEEAM treated cells $(100 \mu \mathrm{g} / \mathrm{ml})$ emitted orange fluorescence that may be attributed to the condensed and fragmented nuclei. In addition, the HEEAM treated cells $(200 \mu \mathrm{g} / \mathrm{ml})$ also exhibited the distinct reddish orange fluorescence that corresponds to the loss of membrane integrity, and chromatin condensation, putatively due to apoptosis. These results were also in agreement with standard doxorubicin treatments. Moreover, the tested concentrations of $A$. muricata leaves extract ( 200 and $400 \mathrm{mg} / \mathrm{kg} \mathrm{bw}$ ) also exerted protection activity in vivo from the deleterious effect of DLA-induced tumor in mice (Nalini and Brindha 2018).

Organic solvent extracts of $A$. muricata using several solvents have reported to induce cytotoxicity, apoptosis, cell cycle arrest and necrosis thereby inhibiting cancer cell motility, migration, metastasis and proliferation (Abdul et al. 2018). The cytotoxic effects of $A$. muricata leaves extracts were clearly demonstrated in human A375 melanoma (Ménan et al. 2006), head and neck squamous cell SCC-25 carcinoma (Magadi et al. 2015), Liver HepG2 (Liu et al. 2016) colorectal (HT-29 and HCT-116) (Moghadamtousi et al., 2015), pancreatic (CD18/HPAF and FG/COLO357) (Torres et al. 2012), pancreatic Capan-1 cancer cells (Rosdi et al. 2015) and lung A549 (Moghadamtousi et al. 2014) cancer cell lines. Extracts from seeds were reportedly toxic to hepatic Hep G2 (Moghadamtousi et al. 2014) cancer cells. On the other hand, extracts obtained from leaf, pericarp, seed and stem reported to exert cytotoxicity in hematological malignant cells like leukemia U-937 cell line (Liu et al. 2016, Santhosh et al. 2015). 
Besides, ACGs, the major phytoconstituents, possibly induce cytotoxicity, by inhibiting mitochondrial complex I, involved in oxidative phosphorylation leading to impaired ATP synthesis (McLaughlin 2008). As cancer cells demand higher ATP load than the normal cells, inhibitors targeting mitochondrial complex I, possibly, may be entailing greater potential in cancer treatments (Deep et al. 2016).

\section{Gas Chromatography and Mass Chromatography (GC-MS)}

The major phytoconstituents of HEEAM were identified using GC-MS analysis (Figure 3). GC-MS methods aids in the identification of the phytoconstituents based on the retention time, peak area, molecular formula and molecular weight. The compounds were identified by matching the chromatograms and the concomitant mass peaks with NIST08 spectral database. Sixteen compounds were identified in HEEAM by GC-MS methods (Table2). The major compounds were palmitic acid (9.48\%), propyne $(9.48 \%)$, stearic acid (6.44\%), syramine (5.95\%), 2,4-di-tertiary-butyl phenol (3.84\%), di (2-ethylhexylpalmitate) (3.63\%), ethyl palmitate (3.75\%), vitamin $\mathrm{E}(5.37 \%)$, bicyclo (2.2.2) octane-1-carboxylic acid (5.95\%), 6-methyl- 2tridecanone (3.65\%), 9-icosyne (3.01\%), geraniol (4.31\%), 25, 26 dihydroxycholecalciferol (4.49\%), 3,7,11,15-tetramethyl-2-hexadecen-1-ol (4.41\%), stigmast-5-en-3-ololeate (4.12\%), triglyL'Carnitine (4.31\%). Biochemical analysis of hydroethanolic extract of $A$. muricata from the earlier study also indicated the presence of numerous flavonoids, phenolics, steroids, saponins, tannins, alkaloids and antioxidants (Nalini and Brindha 2018). The composition of HEEAM extract indicated that primarily it comprises phenolic compounds, which are potent antioxidants (Pourreza 2013). Qazi et al., (2018) have also reported the presence of alkaloids and annonaceous acetogenins (ACGs), isoquinoline, flavonoids in $A$. muricata leaves, fruit, bark, and roots.

\section{Model validation and refinement}

The Ramachandran plot depicting the phi/psi dihedral angles of energy minimized structures generated by Rampage server is presented in Figure 4. The number of residues in the favoured, allowed and outlier regions of the Ramachandran plot are summarized in Table 3. The overall model quality predicted by ProSA is represented as Z-score (Wiederstein and Sippl 2007). This score helps us to determine if the refined structure falls within the ranges of the protein structures that are available in the PDB (Doss et al. 2012). Z-score for SwissModel generated models of BCL2, COX2, NAT2 and p53 were -6.79, -8.84, -7.62 and -1.25 , respectively. These results indicated that the models generated from SwissModel were better and can be chosen for further docking studies.

\section{Docking simulation}

Computer Aided Drug Design (CADD) serves as a valuable alternative to conventional drug development methods. Phytoconstituents of HEEAM were docked to anti-apoptotic proteinBCL2, besides COX2, NAT2 and p53 enzymes to evaluate their potential interactions when compared with the drug doxorubicin. Docking results of HEEAM phytoconstituents and standard drug doxorubicin against the targets (BCL2, COX2, NAT2 and p53) of our choice (Table 4) are displayed in Figure 5. These phytoconstituents were chosen for the docking simulation because of their potent anticancer activities (Moghadamtousi et al. 
2015), which further motivated us to investigate their interaction with above mentioned targets for cancer chemotherapeutics.

Docking study was performed using AutoDock4.2. Dockings that resulted in lowest docking energy with higher number of hydrogen bonds were selected (Table 4). Docking of HEEAM phytoconstituentswith NAT2 target showed notable results. Compounds Vitamin E, 2,4-di-tert-butyl phenol and 6-methyl- 2tridecanone showed strong interaction with NAT2 enzyme with binding scores of $-10.08,-6.8$ and -5.99 $\mathrm{kcal} / \mathrm{mol}$, respectively, due to the formation of one hydrogen bonding each. However, compound tyramine had a score of -5.62 and it formed 3 hydrogen bonding interactions. Positive control drug, doxorubicin showed a score of $-9.18 \mathrm{kcal} / \mathrm{mol}$ and it formed 4 hydrogen bonds with the NAT2 enzyme (Table 4). 3dimensional modeling and docking simulations of human NAT2 proteins, have provided more insight into the functional properties revealing a larger substrate binding pocket with a cleft in NAT2, possibly contributing to different substrate specificities (Wu et al. 2007). N-Acetyl transferase catalyses the transfer of acetyl groups from acetyl CoA to Arylamines. Arylamine N-Acetyl transferase 2 (NAT2) metabolizes arylamine present in most xenobiotic chemicals, viz., drug compounds and carcinogens, and toxicants (Zhou et al. 2013). These polymorphic NAT2 enzymes activated the heterocyclic aromatic amines (HAAs) present in the diet to putative carcinogenic activation products that are implicated in the incidence of a wide range of cancers (George et al. 2012; Rahman et al. 2014). Higher NAT2 enzyme activity is associated with increased risk of colon cancer by activating HAAs in colon (Shadrack and Ndesendo 2017). Hence, the inhibition of NAT2 enzyme activity most likely plays a major role in colon cancer prevention and treatment.

Like docking with NAT2 enzyme, COX2 enzymes too showed interesting results. Compounds vitamin E, 2,4-di-tert-butyl phenol and 6-methyl- 2-tridecanone showed strong interaction with COX2 enzyme with binding scores of $-8.39,-7.53$ and $-6.55 \mathrm{kcal} / \mathrm{mol}$, respectively. The compounds vitamin $\mathrm{E}$ and 2,4-di-tertbutyl phenol formed one hydrogen bond, while 6-methyl- 2-tridecanone formed 3 hydrogen bonds. Control drug doxorubicin scored a value of $-8.22 \mathrm{kcal} / \mathrm{mol}$ as it formed 3 hydrogen bonds with the COX2 enzyme (Table 3). Cyclooxygenase-2 (COX2), an important enzyme in the inducible prostaglandin metabolism, possibly mediating inflammatory response leading to other adverse disorders like cancer (Mahboubi and Zarghi 2019). Besides that, their expression was observed at higher levels only in inflammatory lesions and tumor cases but not in normal cells (Tseng et al. 2016). The catalytic domain COX2 comprises bulk of the protein, contains the cyclooxygenase and peroxidase active sites on either side of the heme prosthetic group (Smith et al. 2000, Mbonye et al. 2008). We clearly observed the compounds interacting in the immediate vicinity of amino acid residues close to Tyr-385, the critical catalytic amino acid for the cyclooxygenase 'catalytic' reaction (Smith et al. 2000, Mbonye et al. 2008, Garavito et al, 2002). Thus, COX2 remains as an attractive and potential target in the development of anti-inflammatory, antitumor, and antimetastatic therapeutic agents.

The third target of our interest is the anti-apoptotic protein BCL2 that plays a crucial role in the regulation and execution of apoptosis in many types of cancers thus targeting BCL2 will form a very valuable adjuvant to current cancer therapies (Campbell and Tait 2018). From our docking analysis, we found 
compounds 2,4-di-tert-butyl phenol, vitamin E and tyramine showed strong interaction with BCL2 enzyme with binding scores of $-5.83,-5.73$ and $-7.87 \mathrm{kcal} / \mathrm{mol}$, respectively. The compounds 2,4-di-tert-butyl phenol and vitamin $\mathrm{E}$ formed one hydrogen bond, while tyramine formed 2 hydrogen bonds. Control drug doxorubicin showed a score of $-5.82 \mathrm{kcal} / \mathrm{mol}$ and formed 4 hydrogen bonds with the BCL2 enzyme (Table 4). BCL2 family proteins are basically of two classes, one that promotes (pro-apoptotic) and the other that inhibits (anti-apoptotic) apoptosis. Theproapoptotic site unique to BCL-2is observed at R104, Y105, R106, and R107 that are conserved, and R103 (Katz et al. 2008). In our study, we observed the compounds interacting in this region of the protein. Any disturbance to the homeostasis of pro-apoptotic and anti-apoptotic BCL2 proteins may lead to a wide range of disorders including cancer (Sathishkumar et al. 2012).

The final target of our interest is p53, a nuclear transcription factor with a pro-apoptotic function. Docking results showed that compounds tyramine, bicyclo (2.2.2) octane-1-carboxylic acid and 6-methyl- 2tridecanone may be exhibiting strong interaction with $p 53$ with binding scores of $-4.91,-4.05$ and -4.03 $\mathrm{kcal} / \mathrm{mol}$, respectively. The compounds tyramine formed two hydrogen bonds, while compounds bicyclo (2.2.2) octane-1-carboxylic acid and formed 3 hydrogen bonds. Control drug doxorubicin showed a score of $-5.53 \mathrm{kcal} / \mathrm{mol}$ and formed 3 hydrogen bonds with the p53 target (Table 4). Since p53 plays an important role in the regulation of cells in response to DNA damage, strategies on p53-mediated activation of pro-apoptotic pathway and/or elimination of dominant-negative effect of mutant p53 on wild-type p53 can be focused on basis of therapeutic implications (Ozaki and Nakagawara 2011).

From the results of our current study, it is clear that the most effective bioactive compounds from $A$. muricata could be considered as the putative lead scaffold entities for the design and synthesis of effective therapeutic drug compounds. Relatively new but rapidly developing science, the Nanomedicine, uses nanoscale materials, in the nano range $\left(10^{-9} \mathrm{~m}\right)$, as potential diagnostic tools or to deliver therapeutic agents at specific 'target' sites, in a controlled and sustainable manner (Patra et al. 2018). De novo synthetic methods (Mohandes and Niasari 2014a, 2014b, Goudarzi et al. 2016, Amiri et al. 2017, Amiri et al. 2018) could therefore improve both the efficacy of novel as well as old drugs besides imparting more beneficial attributes in treating chronic human disorders.

\section{Conclusion}

Worldwide, cancer remains a leading cause of preventable death. By virtue of their putative therapeutic potential, natural products derived from plants may entail greater promise in the treatment of cancer (Paul et al. 2013). The present study demonstrated the anticancer potential of chemical constituents present in $A$. muricata by providing insights into its putative bioactivities through in vitro studies and further facilitated the elucidation of the molecular mechanisms of action for these phytoconstituents with the help of molecular docking studies. Although these properties are appreciable in vitro and in silico, in order to ascertain whether $A$. muricata can be exploited as a potential source for new anticancer medicine more detailed pharmacological assessment studies on safety, efficacy and putative toxicological profile is warranted. 


\section{Declarations}

\section{Ethics approval and consent to participate}

Not applicable

\section{Consent for publication}

Not applicable

\section{Availability of data and materials}

Not applicable

\section{Competing interests}

The authors declare that they have no competing interests

\section{Funding}

Not applicable

\section{Authors' contributions}

Conceptualization, DB and KSl; methodology, PN and KSI; supervision and project administration, DB. All authors read and approved the final manuscript.

\section{Acknowledgements}

The authors are thankful to the Management, Secretary and Principal of PSG College of Arts and Science, Coimbatore, Tamil Nadu, India, for providing necessary infrastructural facilities.

\section{References}

Abdul WSM, Jantan I, Haque MA, Arshad L (2018) Exploring the Leaves of Annona muricata L. as a Source of Potential Anti-inflammatory and Anticancer Agents. Frontiers in pharmacology 9(661):1-20

Alali FQ, Liu XX, McLaughli JL (1999) Annonaceous acetogenins: Recent progress. J Nat Prod 62:504540

Amiri M, Ahmad A, Meysam A, Abbas P, Masoud SN (2018) Synthesis and in vitro evaluation of a novel magnetic drug delivery system; proecological method for the preparation of CoFe2O4 nanostructures. J Mol Liq 249:1151-1160

Amiri, M, Salavati NM, Akbari A (2017) A magnetic CoFe204/SiO2 nanocomposite fabricated by the solgel method for electro catalytic oxidation and determination of L-cysteine. Micro chim Acta 184: 825-833 
Badrie N, Schauss AG (2009) Soursop (Annona muricata L.): composition, nutritional value, medicinal uses, and toxicology in Bioactive Foods in Promoting Health, R. R. Watson and V. R. Preedy, Eds., Oxford. 39: 621-643

Biasini M, Bienert S, Waterhouse A, Arnold K, Studer G, Schmidt T, Kiefer F, Cassarino TG, Bertoni M, Bordoli L, Schwede T (2014) SWISS-MODEL: modelling protein tertiary and quaternary structure using evolutionary information. Nucleic Acids Res 42:252-258.

Campbell KJ, Tait SWG (2018) Targeting BCL-2 regulated apoptosis in cancer. Open Biol 8(5):1-38 Chang ER, Wu YC (2001) Novel cytotoxic Annonaceous acetogenins from Annona muricata. J Nat Prod 64:925-931

Coria-Téllez AV, Montalvo GE, Yahia EM, Obledo VE (2016) Annona muricata: A comprehensive review on its traditional medicinal uses, phytochemicals, pharmacological activities, mechanisms of action and toxicity. Arab J Chem 11(5): 662-691

Dai Y, Hogan S, Schmelz EM, Ju YH, Canning C, Zhou K (2011) Selective growth inhibition of human breast cancer cells by Graviola fruit extract in vitro and in vivo involving down regulation of EGFR expression. Nutr Cancer 63:795-801

Daina A, Michielin O, Zoete V (2017) Swiss ADME: a free web tool to evaluate pharmacokinetics, druglikeness and medicinal chemistry friendliness of small molecules. Sci Rep 7:42717. https://doi.org/10.1038/srep42717

De Souza R, Benassi E, da Silva RR, Afonso S, Scarminio IS (2009) Enhanced extraction yields and mobile phase separations by solvent mixtures for the analysis of metabolites in Annona muricata L. J Sep Sci 32:4176-4185

Deep G, Kumar R, Anil KJ, Dhar D, Panigrahi GK, Hussain A, Agarwal C, El-Elimat T, Sica VP, Oberlies NH, Agarwal R (2016) Graviola inhibits hypoxia-induced NADPH oxidase activity in prostate cancer cells reducing their proliferation and clonogenicity. Sci Rep 6:23135

Doss CG, Rajith B, Garwasis N, Mathew PR, Raju AS, Apoorva K, William D, Sadhana NR, Himani T, Dike IP (2012) Screening of mutations affecting protein stability and dynamics of FGFR1-a simulation analysis. Appl Transl Genom 1:37-43

Ferlay J, Soerjomataram I, Dikshit R, Eser S, Mathers C, Rebelo M, Parkin DM, Forman D, Bray F (2015) Cancer incidence and mortality worldwide: sources, methods and major patterns in GLOBOCAN. Int J Cancer 1:136(5):E359-386

Garavito RM, Malkowski MG, DeWitt DL (2002) The structures of prostaglandin endoperoxide $\quad$ H synthases-1 and -2. Prostaglandins Other Lipid Mediat 68-69: 129-152 
Gasteiger E, Gattiker A, Hoogland C, Ivanyi I, Appel RD, Bairoch A (2003) ExPASy. the proteomics server for in-depth protein knowledge and analysis. Nucleic Acids Res 31:3784-3788

Gavamukulya Y, Wamunyokoli F, El-Shemy HA (2017) Annona muricata: Is the natural therapy to most disease conditions including cancer growing in our backyard? A systematic review of its research history and future prospects. Asian Pac J Trop Med 10(9):835-848

George S, Santhlingam K, Chandran, M, Gangwar P Gururagavan M. Docking (2012) Studies of novel coumarin derivatives as arylamine N-acetyltransferance 2 inhibitors. Asian J Pharm Clin Res 5(1): 94-96

Goudarzi M, Mir N, Mousavi-KM, Bagheri S, Niasari MS (2016) Biosynthesis and characterization of silver nanoparticles prepared from two novel natural precursors by facile thermal decomposition methods. Sci Rep 6:32539

Hajighasemi F, Mirshafiey A (2010) Propranolol effect on proliferation and vascular endothelial growth factor secretion in human immunocompetent cells. J Clin Immunol Immunopathol Res 2: 22-27

Katz C, Benyamini H, Rotem S, Lebendiker M, Danieli T, losub A, Refaely H, Dines M, Bronner V, Bravman T, Shalev DE, Rüdiger S, Friedler A (2008) Molecular basis of the interaction between the antiapoptotic Bcl-2 family proteins and the proapoptotic protein ASPP2. P Natl Acad Sci USA 105(34): 12277-12282

Kerr JFR, Wyllie AH, Currie AR (1972) Apoptosis: a basic biological phenomenon with wide-ranging implication in tissue kinetics. Br J Cancer 26:239-57

Leboeuf M, Cave A, Bhaumik P, Mukherjee B, Mukherjee R (1980) The phytochemistry of the Annonaceae. Phytochemistry 21:2783-2813

Liaw CC, Liou JR, Wu TY et al. Kinghorn A, Falk H, Gibbons S et al., (2016) Acetogenins from Annonaceae. Progress in the chemistry of organic Natural Products 101:113-230 doi: 10.1007/978-3-319-22692-7_2

Liu N, Yang HL, Wang P, Lu YC, Yang YJ, et al (2016) Functional proteomic analysis revels that the ethanol extract of Annona muricata L. induces liver cancer cell apoptosis through endoplasmic reticulum stress pathway. J Ethnopharmacol 2(189): 210-217

Lovell SC, Davis IW, Arendall WB 3rd, de Bakker PI, Word JM, Prisant MG, Richardson JS, Richardson DC (2003) Structure validation by Calpha geometry: phi, psi and $C$ beta deviation. Proteins 50(3):437-50

Magadi VP, Ravi V, Arpitha A, Litha K, Kumaraswamy, K. Manjunath (2015) Evaluation of cytotoxicity of aqueous extract of Graviola leaves on squamous cell carcinoma cell-25 cell lines by 3-(4,5dimethylthiazol-2-YI) -2,5-diphenyl tetrazolium bromide assay and determination of percentage of cell inhibition at G2M phase of cell cycle by flow cytometry: An in vitro study. Contemp Clin Dent 6(4): 529533 
Mahboubi RSMI, Zarghi A (2019) Selective COX-2 inhibitors as anticancer agents: a patent review (20142018). Expert Opin Ther Pat 29(6):407-427. doi: 10.1080/ 13543776. 2019.1623880

Mbonye UR, Yuan C, Harris CE, Sidhu RS, Song I, Arakawa T, Smith WL(2008) Two distinct pathways for cyclooxygenase-2 protein degradation. Biol. Chem 283(13): 8611-8623. doi: 10.1074/jbc.M710137200

McLaughlin JL (2008) Paw and cancer: Annonaceous acetogenins from discovery to commercial products. J Nat Prod 71 (7): 1311-1321. doi: $\quad$ 10.1021/np800191t

Ménan H, Banzouzi JT, Hocquette A, Pelissier Y, Blache Y, Kone M, Mallie M, Assi LA, Valentin A (2006) Antiplasmodial activity and cytotoxicity of plants used in West African traditional medicine for the treatment of malaria. J Ethnopharmacol 105(1-2): 131-136 doi: 10.1016/j.jep.2005.10.027

Mizuta R, Araki S, Furukawa M, Furukawa Y, Ebara S, Shiokawa D, Hayashi K, Tanuma S, Kitamura D (2013) DNase $y$ is the effector endonuclease for internucleosomal DNA fragmentation in necrosis. PLoS One 2.8(12): e80223. doi: 10.1371/journal.pone.0080223

Moghadamtousi SZ, Rouhollahi E, Karimian H, Fadaeinasab M, Firoozinia M, Abdulla MA et al (2015) The chemopotential effect of Annona muricata leaves against azoxymethane induced colonic aberrant crypt foci in rats and the apoptotic effect of acetogenin annomuricin E in HT-29 cells: A bioassay guided approach. PLoS One; 10, doi:10,1371/journal.phone.0122288.

Moghadamtousi ZS, Kadir HA, Paydar M, Rouhollahi E, Karimian H (2014) Annona muricata leaves induced apoptosis in A549 cells through mitochondrial-mediated pathway and involvement of NF-KB. BMC Complem Altern M. 15(14): 299. doi: 10.1186/1472-6882-14-299

Mohandes F, Niasari MS (2014a) Simple morphology-controlled fabrication of hydroxyapatite nanostructures with the aid of new organic modifiers. Chem Eng J. 252: 173-184

Mohandes F, Niasari MS (2014b) In vitro comparative study of pure hydroxyl apatite nanorods and novel polyethylene glycol/graphene oxide/hydroxyapatite nanocomposite. J Nano part Res 16(9): 2604- 2616

Morris GM, Huey R, Lindstrom W, Sanner MF, Belew RK, Goodsell DS, Olson AJ (2009) Autodock4 and AutoDockTools4: automated docking with selective receptor flexibility. J Comput Chem 16: 2785-91

Nalini P and Brindha D (2018) Antitumor potential of hydroethanolic extract of Annona muricata leaves against dalton's lymphoma ascites-induced tumor in mice. Asian J Pharm Clin Res 11(3):364-367

Newman DJ, Cragg GM (2015) Natural products assources of new drugs from 1981 to 2014. J Nat Prod 79 (3):629-661

Oberhammer F, Wilson JW, Dive C, Morris ID, Hickman JA, Wakeling AE, Walker PR, Sikorska M (1993) Apoptotic death in epithelial cells: cleavage of DNA to $300 \mathrm{and} /$ or $50 \mathrm{~kb}$ fragments prior to or in the absence of internucleosomal fragmentation. EMBO J 12(9):3679-84 
Ozaki T, Nakagawara A (2011) Role of p53 in cell death and human cancers. Cancers (Basel) 3(1):9941013

Patra, JK, Das G, Fraceto LF, campos VR, Torres MPR, Torres LSA, Torres LAD, Grillo R, Swamy MK, Sharma S, Habtemariam S, Seung SH (2018) Nano based drug delivery systems: recent developments and future prospects. J Nano biotechnol. 16 (71)

Paul J, Gnanam R, Jayadeepa RM, Arul L (2013) Anti cancer activity on graviola, an exciting medicinal plant extract vs various cancer cell lines and a detailed computational study on its potent anti-cancerous leads. Curr Trop Med Chem 13(14):1666-1673. 1673

Peter B, Bosze S, Horvath R (2017) Biophysical characteristicsof proteins and living cells exposed to the Green teapolyphenol epigallocatechin-3-gallate (EGCg): review of recent advances from molecular mechanisms to nanomedicine and clinical trials. European Biophysics 46(1):1-24

Pourreza N (2013) Phenolic compounds as potential antioxidant. Jundishapur J Nat Pharm Prod $8(4): 149-50$

Pundir S, Martin MJ, O’Donovan C (2017) UniProt protein knowledgebase. Methods Mol Biol 1558: 41-55

Qazi AK, Siddiqui J, Jahan R, Chaudhary S, Walker LA, Sayed Z, Jones DT, Batra SK, Macha MA (2018) Emerging therapeutic potential of graviola and its constituents in cancers. Carcinogenesis 39(4):522-533

Rahman U, Sahar A, Khan MI, Nadeem M (2014) Production of heterocyclic aromatic amines in meet: Chemistry, health risks and inhibition. LWT- Food Sci Technol 59: 229-233

Rosdi M, Daud N, Zulkifli R, and Yaakob H (2015) Cytotoxic effect of Annona muricata Linn leaves extract on Capan-1 cells. J App Pharm Sci. 5(5): 045-048

Santhosh SB, Ragavendran C, Natarajan D (2015) Spectral and HRTEM analyses of Annona muricata leaf extract mediated silver nanoparticles and its Larvicidal efficacy against three mosquito vectors Anopheles stephensi, Culexquinque fasciatus, and Aedesaegypti. J Photoch Photobio B 153: 184-190

Sathishkumar N, Sathiyamoorthy S, Ramya M, Yang DU, Lee HN, Yang DC (2012) Molecular docking studies of anti-apoptotic BCL-2, BCL-XL, and MCL-1 proteins with ginsenosides from Panax ginseng. J Enzym Inhib Med Chem 27(5):685-92

Shadrack DM, Ndesendo VMK (2017) Molecular docking and ADMET Study of emodin derivatives as anticancer inhibitors of NAT2, COX2 and TOP1 enzymes. Comput Mol Biosci 7: 1-18

Shailaja K, Gustavo P, Amarant- M, Deborah F, Thomas B, Eha BW, Douglas R. Green (2006) Acridine orange/ Ethidium bromide (AO/EB) staining to detect apoptosis. Cold Spring Harbor Laboratry press, Cold Spring Harbor protocols, NY, USA 
Smith WL, DeWitt DL, Garavito RM (2000) Cyclooxygenases: structural, cellular, and molecular biology. Annu. Rev. Biochem 69 145-182

Sun S, Liu J, Zhou N, Zhu W, Dou QP, Zhou, K. (2016) Isolation of three new annonaceous acetogenins fromgraviola fruit (Annona muricata) and their anti-proliferation on human prostate cancer cell PC-3. Bioorganic Med. Chem. Lett 26:4382-4385

Syed Najmuddin SUF, Romli MF, Hamid M, Alitheen NB, Abd Rahman NMA (2016) Anti-cancer effect of Annona muricata Linn leaves crude extract (AMCE) on breast cancer cell line. BMC Complement Altern Med 16: 311

Torres MP, Rachagani S, Purohit V, Pandey P, Joshi S, Moore ED. Johansson SL, Singh PK Ganti AK, Batra SK (2012) Graviola: a novel promising natural-derived drug that inhibits tumorigenicity and metastasis of pancreatic cancer cells in vitro and in vivo through altering cell metabolism. Cancer Lett 323: 29-40. doi: 10.1016/j.canlet.2012.03.031

Tseng TS, Chuang SM, Hsiao NW, Chen YW, Lee YC, Lin CC, Huang C, Tsai KC (2016) Discovery of a potent cyclooxygenase-2 inhibitor, $\mathrm{S} 4$, through docking-based pharmacophore screening, in vivo and in vitro estimations. Mol Biosyst 19; 12(8):2541-51

Van gunsteren VWF, Billeter SR, Eising AA, Hünenberger PH, Krüger P, Mark AE, Scott WRP, Tironi IG (1996) Biomolecular simulation: the GROMOS96 manual and user guide. Verlagder Fachvereine Hochschulverlag AG an der ETH Zürich 1-1042

Wang JL, Limburg D, Graneto MJ, Springer J, Rogier J, Hamper B, Liao S, Pawlitz JL, Kurumbail RG, Maziasz T, Talley JJ, Kiefer JR, Carter J (2010) The Novel benzopyran class of selective cyclooxygenase2 inhibitors-Part II: The Second cinical candidate having a shorter and favorable human half- Life. Bioorg Med Chem Lett 20:7159-7163

Wiederstein M, Sippl MJ (2007) ProSA-web: interactive web service for the recognition of errors in threedimensional structures of proteins Nucleic Acids Res 35 (Web Server issue) 407-410

Wu H, Dombrovsky L, Tempel W, Martin F, Loppnau P, Goodfellow GH, Grant DM, Plotnikov AN (2007) Structural basis of substrate-binding specificity of human arylamine $\mathrm{N}$-acetyltransferases. J Biol Chem 282(41): 30189-30197

Wu H, Tempel W, Dombrovski L, Loppnau P, Weigelt J, Sundstrom M, Arrowsmith CH, Edwards AM, Bochkarev A, Grant DM, Plotnikov AN (2007) Structural basis of substrate-binding specificity of human arylamine N acetyltransferases. Structural Genomics Consortium. J Biol Chem 282:30189-30197

Wyllie AH (1980) Glucocorticoid induced thymocyte apoptosis is associated with endogenous endonuclease activation. Nature 284:555-556 
Xu D, Zhang Y (2011) Improving the physical realism and structural accuracy of protein models by a twostep atomic-level energy minimization. Biophys J 101: 2525-2534

Zhou X, Ma Z, Dong D, Wu B (2013) Arylamine N-acetyltransferases: a structural perspective. Br J Pharmacol 169(4):748-60

\section{Tables}

Table 1: In vitro cytotoxicity by MTT assay

Concentration $(\mu \mathrm{g} / \mathrm{ml}) \quad$ Cytotoxicity $(\%) \quad \mathrm{IC}_{50}$ value $(\mu \mathrm{g} / \mathrm{ml})$

\begin{tabular}{cll}
\hline 25 & $20.19 \pm 1.26$ & 185.585 \\
50 & $37.26 \pm 0.77$ & \\
100 & $49.25 \pm 1.09$ & \\
200 & $57.36 \pm 0.83$ \\
400 & $69.66 \pm 1.11$ \\
\hline
\end{tabular}

Table 2: $\quad$ Phytochemical compounds of HEEAM identified in GC-MS Analysis 


\begin{tabular}{|c|c|c|c|}
\hline ame of the compound & CID & $\begin{array}{c}\text { Retention } \\
\text { Time }\end{array}$ & $\begin{array}{l}\text { Peak } \\
\text { area }\end{array}$ \\
\hline
\end{tabular}

\begin{tabular}{|c|c|c|c|c|c|c|}
\hline 1 & Palmitic acid & 985 & 29.866 & 9.48 & C16H32O2 & $\begin{array}{l}256.4 \\
\mathrm{~g} / \mathrm{mol}\end{array}$ \\
\hline 2 & Stearic acid & 5281 & 33.574 & 6.44 & C18H36O2 & $\begin{array}{l}284.48 \\
\mathrm{~g} / \mathrm{mol}\end{array}$ \\
\hline 3 & Tyramine & 5610 & 2.054 & 5.95 & C8H11NO & $\begin{array}{l}137.182 \\
\mathrm{~g} / \mathrm{mol}\end{array}$ \\
\hline 4 & Propyne & 6335 & 4.862 & 9.48 & $\mathrm{C} 3 \mathrm{H} 4$ & $\begin{array}{l}40.065 \\
\mathrm{~g} / \mathrm{mol}\end{array}$ \\
\hline 5 & 2,4 di -tert-butyl phenol & 7311 & 20.091 & 3.84 & $\mathrm{C} 14 \mathrm{H} 22 \mathrm{O}$ & $\begin{array}{l}206.329 \\
\mathrm{~g} / \mathrm{mol}\end{array}$ \\
\hline 6 & $\begin{array}{l}\text { Di (2-ethyl hexyl) } \\
\text { phthalate }\end{array}$ & 8343 & 39.812 & 3.63 & $\mathrm{C} 24 \mathrm{H} 38 \mathrm{O} 4$ & $\begin{array}{l}390.564 \\
\mathrm{~g} / \mathrm{mol}\end{array}$ \\
\hline 7 & Ethyl palmitate & 12366 & 30.383 & 3.75 & C18H36O2 & $\begin{array}{l}284.484 \\
\mathrm{~g} / \mathrm{mol}\end{array}$ \\
\hline 8 & Vitamin E & 14985 & 49.367 & 5.37 & C29H50O2 & $\begin{array}{l}430.717 \\
\mathrm{~g} / \mathrm{mol}\end{array}$ \\
\hline 9 & $\begin{array}{l}\text { Bicyclo }(2.2 .2) \text { octane- } \\
\text { 1-carboxilic acid }\end{array}$ & 136534 & 2.054 & 5.95 & $\mathrm{C} 9 \mathrm{H} 14 \mathrm{O} 2$ & $\begin{array}{l}154.209 \\
\mathrm{~g} / \mathrm{mol}\end{array}$ \\
\hline 10 & $\begin{array}{l}\text { 6-methyl- } 2 \text { - } \\
\text { tridecanone }\end{array}$ & 547006 & 27.44 & 3.65 & $\mathrm{C} 14 \mathrm{H} 28 \mathrm{O}$ & $\begin{array}{l}212.377 \\
\mathrm{~g} / \mathrm{mol}\end{array}$ \\
\hline 11 & 9-icosyne & 557019 & 27.808 & 3.01 & C20H38 & $\begin{array}{l}278.524 \\
\mathrm{~g} / \mathrm{mol}\end{array}$ \\
\hline 12 & Geraniol & 637566 & 38.754 & 431 & C10H18O & $\begin{array}{l}154.253 \\
\mathrm{~g} / \mathrm{mol}\end{array}$ \\
\hline 13 & $\begin{array}{l}\text { 25,26- Dihdroxy } \\
\text { cholecalciferol }\end{array}$ & 5364803 & 47.967 & 4.49 & $\mathrm{C} 27 \mathrm{H} 44 \mathrm{O} 3$ & $\begin{array}{l}416.646 \\
\mathrm{~g} / \mathrm{mol}\end{array}$ \\
\hline 14 & $\begin{array}{l}\text { 3,7,11,15- Tetramethyl- } \\
\text { 2-hexadecen-1-ol }\end{array}$ & 5366244 & 32.602 & 4.41 & $\mathrm{C} 20 \mathrm{H} 40 \mathrm{O}$ & $\begin{array}{l}296.539 \\
\mathrm{~g} / \mathrm{mol}\end{array}$ \\
\hline 15 & $\begin{array}{l}\text { Stigmast-5-en-3-ol, } \\
\text { oleate }\end{array}$ & 20831071 & 48.399 & 4.12 & $\mathrm{C} 47 \mathrm{H} 82 \mathrm{O} 2$ & $\begin{array}{l}679.171 \\
\mathrm{~g} / \mathrm{mol}\end{array}$ \\
\hline 16 & Tiglylcarnitine & 22833596 & 38.754 & 4.31 & $\mathrm{C} 12 \mathrm{H} 21 \mathrm{NO} 4$ & $\begin{array}{l}243.303 \\
\mathrm{~g} / \mathrm{mol}\end{array}$ \\
\hline
\end{tabular}

Table 3: Number of residues in different regions of Ramachandran plot. 


\begin{tabular}{llrr}
\hline Model & $\begin{array}{c}\text { Residues in favoured } \\
\text { regions }\end{array}$ & $\begin{array}{c}\text { Residues in allowed } \\
\text { regions }\end{array}$ & $\begin{array}{c}\text { Residues in outlier } \\
\text { regions }\end{array}$ \\
\hline BCL2 & $184(92.5 \%)$ & $6(3.0 \%)$ & $9(r .5 \%)$ \\
COX2 & $537(97.8 \%)$ & $12(2.2 \%)$ & 0 \\
\hline NAT2 & $281(97.9 \%)$ & $5(1.7 \%)$ & $1(0.3 \%)$ \\
\hline p53 & $135(84.4 \%)$ & $20(12.5 \%)$ & $5(3.1 \%)$ \\
\hline
\end{tabular}

Table 4: Binding energies of the bioactive compounds in HEEAM with different targets and Doxorubicin as control 


\begin{tabular}{|c|c|c|c|c|c|}
\hline Targets & Ligands & $\begin{array}{l}\text { Pose } \\
\text { No }\end{array}$ & $\begin{array}{l}\text { Binding } \\
\text { energy }\end{array}$ & $\begin{array}{l}\mathrm{H} \\
\text { Bonds }\end{array}$ & Interacting amino acids \\
\hline \multirow[t]{10}{*}{$\mathrm{COX} 2$} & Vitamin E & 2 & -8.39 & 1 & THR 192 \\
\hline & 2,4 di- tert- butyl phenol & 3 & -7.53 & 1 & THR 192 \\
\hline & 6-methyl-2-tridecanone & 2 & -6.55 & 2 & THR 198, THR 198 \\
\hline & Tetramethyl-2-hexadecen-o-l & 3 & -6.23 & 1 & THR 198 \\
\hline & Palmitic acid & 2 & -5.92 & 3 & THR 198, THR 198, \\
\hline & $\begin{array}{l}\text { Bicyclo octane-1-carboxilic } \\
\text { acid }\end{array}$ & 2 & -5.67 & 1 & SER 516 \\
\hline & Tyramine & 5 & -5.22 & 3 & THR371, THR 192, \\
\hline & Geraniol & 6 & -5.21 & 3 & THR 198, THR 198 \\
\hline & Tiglylcarnitine & 2 & -5.14 & 4 & THR198, ASN368 \\
\hline & Doxorubin & 5 & -8.22 & 3 & $\begin{array}{l}\text { HIS 193, TRP373, HIS200, } \\
\text { ASN368 }\end{array}$ \\
\hline \multirow[t]{10}{*}{ BCL2 } & 2,4 di- tert- butyl phenol & 1 & -5.83 & 1 & ALA 100 \\
\hline & Vitamin E & 7 & -5.73 & 1 & ARG 146 \\
\hline & Tyramine & 1 & -4.87 & 2 & ASP 103, ALA 100 \\
\hline & $\begin{array}{l}\text { Bicyclo octane-1-carboxilic } \\
\text { acid }\end{array}$ & 10 & -4.75 & 1 & ARG 107 \\
\hline & 6-methyl-2-tridecanone & 1 & -4.52 & 0 & \\
\hline & Geraniol & 2 & -4.5 & 2 & ASP 103, ARG107 \\
\hline & Tetramethyl-2-hexadecen-o-l & 3 & -4.34 & 1 & ASN 143 \\
\hline & Palmitic acid & 1 & -3.32 & 0 & \\
\hline & Tiglylcarnitine & 9 & -2.91 & 1 & GLY145 \\
\hline & Doxorubin & 1 & -5.82 & 4 & VAL122, TRP188, ASN192 \\
\hline \multirow[t]{10}{*}{ NAT2 } & Vitamin E & 4 & -10.08 & 1 & THR 289 \\
\hline & 2,4 di- tert- butyl phenol & 3 & -6.8 & 2 & SERR287, THR 289 \\
\hline & Tetramethyl-2-hexadecen-o-l & 4 & -6.36 & 1 & SER216 \\
\hline & 6-methyl-2-tridecanone & 7 & -5.99 & 1 & HIS 107 \\
\hline & Tyramine & 1 & -5.62 & 3 & LYS188, SER127, SER128 \\
\hline & Palmitic acid & 1 & -5.47 & 0 & \\
\hline & Geraniol & 4 & -5.07 & 2 & THR289, SER127 \\
\hline & $\begin{array}{l}\text { Bicyclo octane-1-carboxilic } \\
\text { acid }\end{array}$ & 1 & -4.97 & 2 & THR289, THR289 \\
\hline & Tiglylcarnitine & 6 & -4.79 & 2 & SER216, PHE216 \\
\hline & Doxorubin & 2 & -9.18 & 4 & SER125, THR289, LYS188 \\
\hline \multirow[t]{10}{*}{ p53 } & Tyramine & 8 & -4.91 & 3 & GLU346, GLU349, GLN331 \\
\hline & 2,4 di- tert- butyl phenol & 2 & -4.3 & 1 & GLN331 \\
\hline & $\begin{array}{l}\text { Bicyclo octane-1-carboxilic } \\
\text { acid }\end{array}$ & 2 & -4.05 & 2 & ARG333, ARG333 \\
\hline & 6-methyl-2-tridecanone & 3 & -4.03 & 3 & GLU336 \\
\hline & Vitamin E & 5 & -3.98 & 1 & ARG333 \\
\hline & Geraniol & 4 & -3.67 & 2 & ARG342, GLU346 \\
\hline & Tiglylcarnitine & 4 & -3.41 & 3 & ARG333, GLN331, ARG333 \\
\hline & Tetramethyl-2-hexadecen-o-l & 1 & -3.31 & 1 & LYS351 \\
\hline & Palmitic acid & 7 & -1.37 & 2 & ARG333 \\
\hline & Doxorubin & 1 & -5.53 & 3 & ARG 333, GLU 346 \\
\hline
\end{tabular}




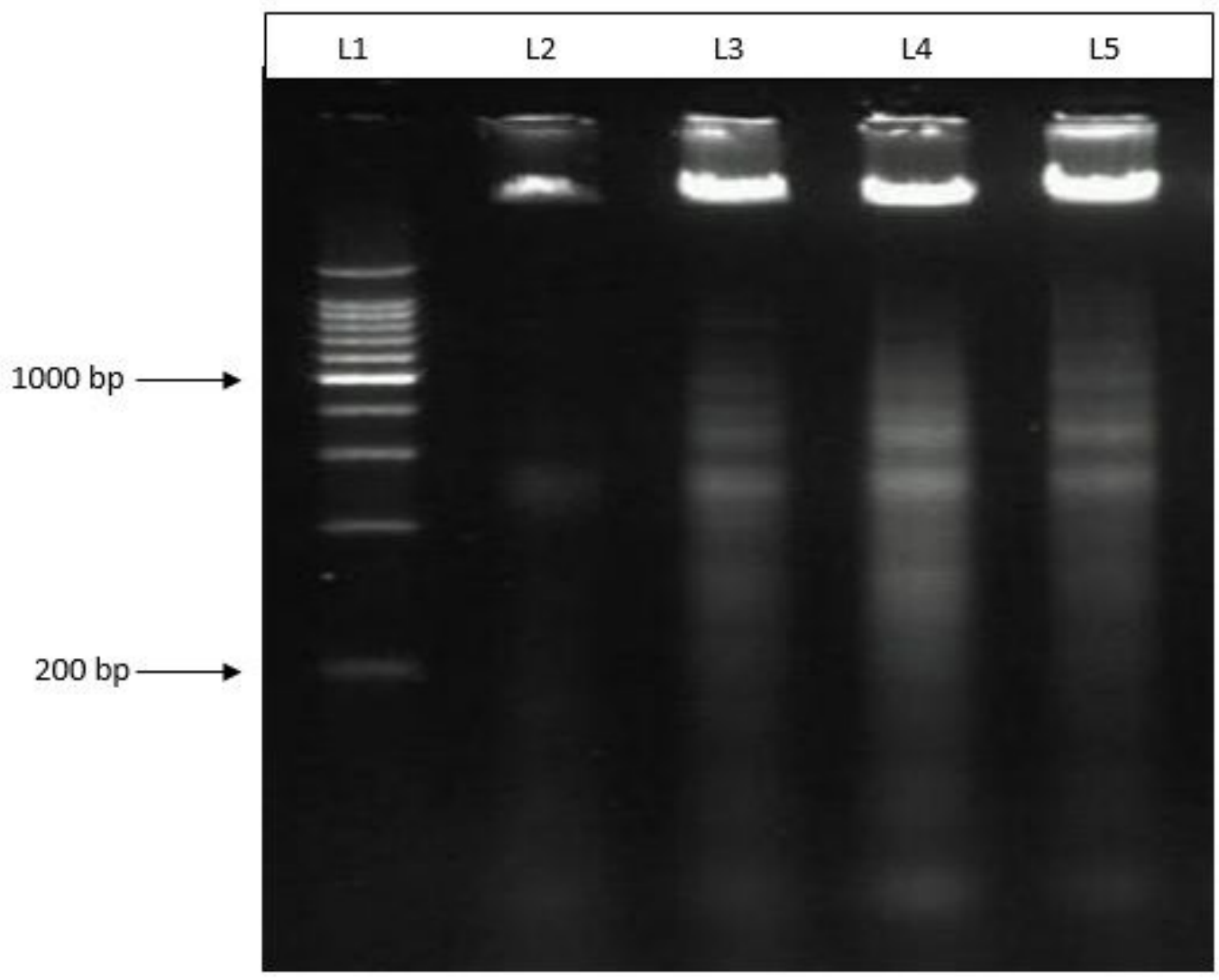

\section{Figure 1}

DNA fragmentation assay. Lane 1: 200bp DNA marker; Lane 2: DLA cell line (untreated); Lane 3: DLA cell line treated with HEEAM $(100 \mu \mathrm{g} / \mathrm{ml})$; Lane 4: DLA cell line treated with HEEAM $(200 \mu \mathrm{g} / \mathrm{ml})$; Lane 5 : DLA cell line treated with doxorubicin $(10 \mu \mathrm{g} / \mathrm{ml})$ 

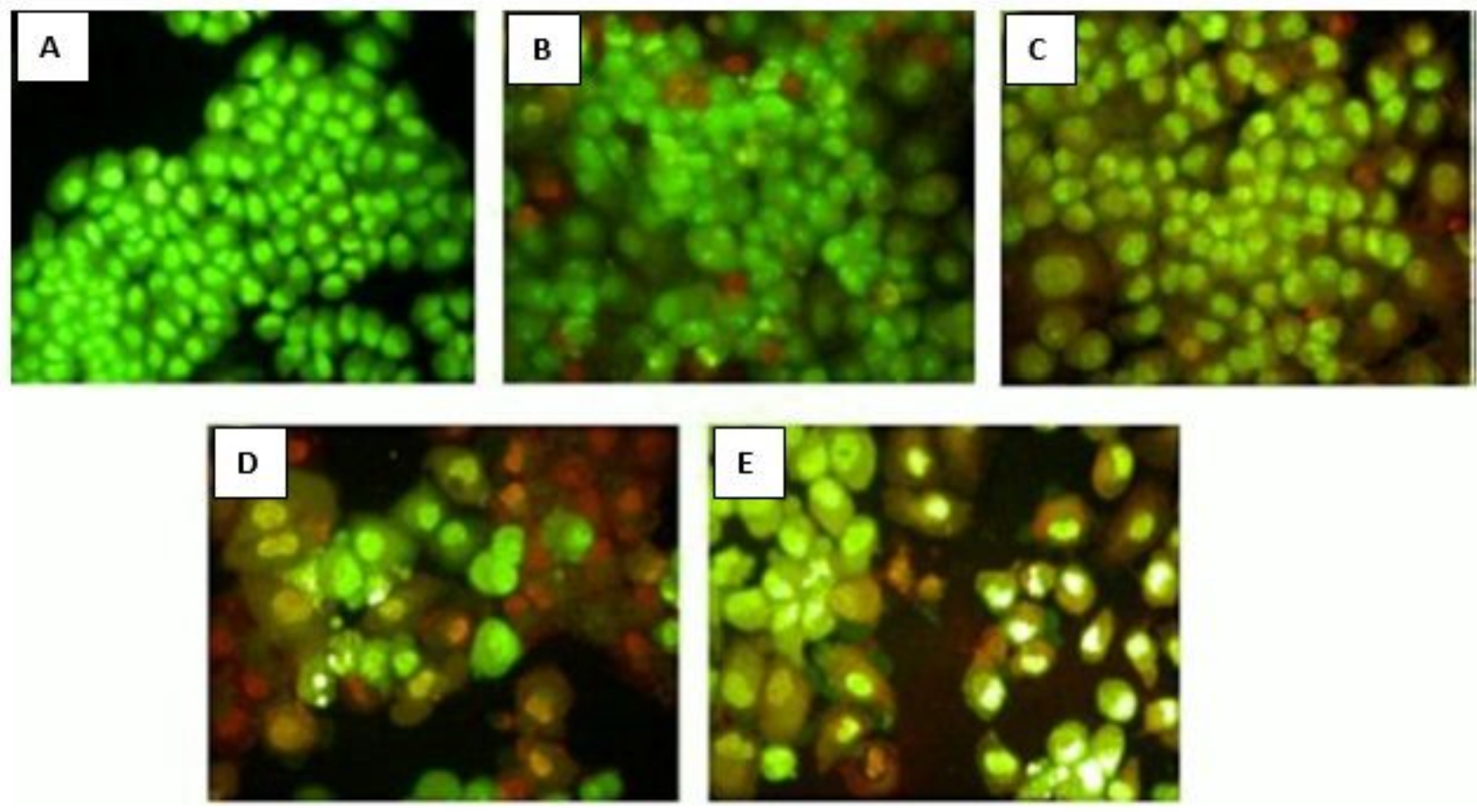

Figure 2

Acridine Orange/ Ethidium Bromide dual staining method. A. DLA cell line (control; untreated); B. DLA cell line treated with HEEAM $(50 \mu \mathrm{g} / \mathrm{ml})$; C. DLA cell line treated with HEEAM $(100 \mu \mathrm{g} / \mathrm{ml}) ;$ D. DLA cell line treated with HEEAM $(200 \mu \mathrm{g} / \mathrm{ml})$. E. DLA cell line treated with doxorubicin $(10 \mu \mathrm{g} / \mathrm{ml})$ drug

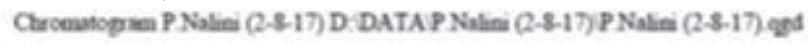

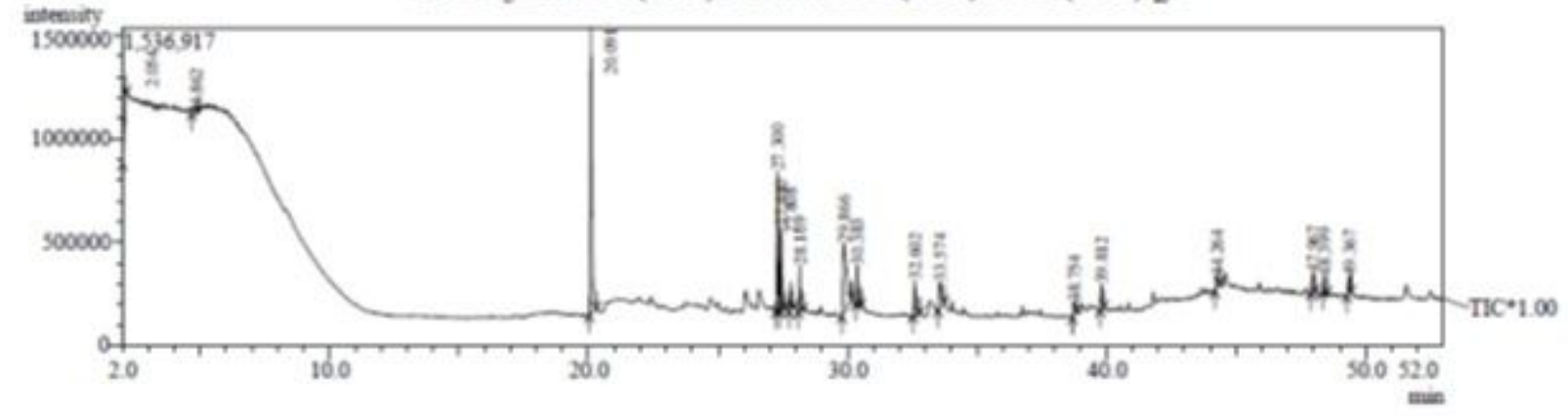

Figure 3

GC-MS analysis of HEEAM 

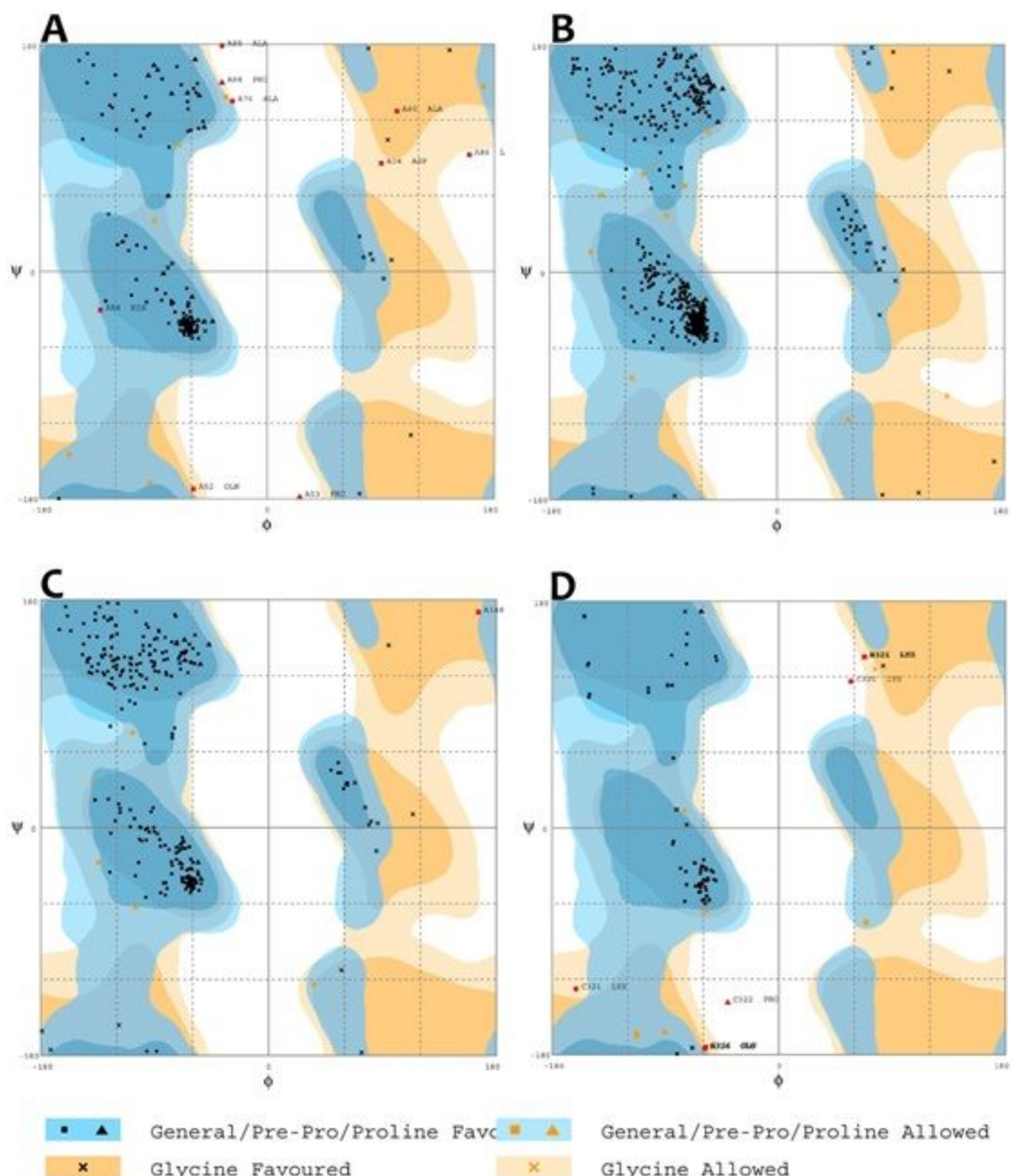

General/Pre-Pro/Proline Allowed Glycine Allowed

\section{Figure 4}

Ramachandran plot analysis of the energy minimized structures. A) BCL2, B) COX2, C) NAT2 and D) p53 

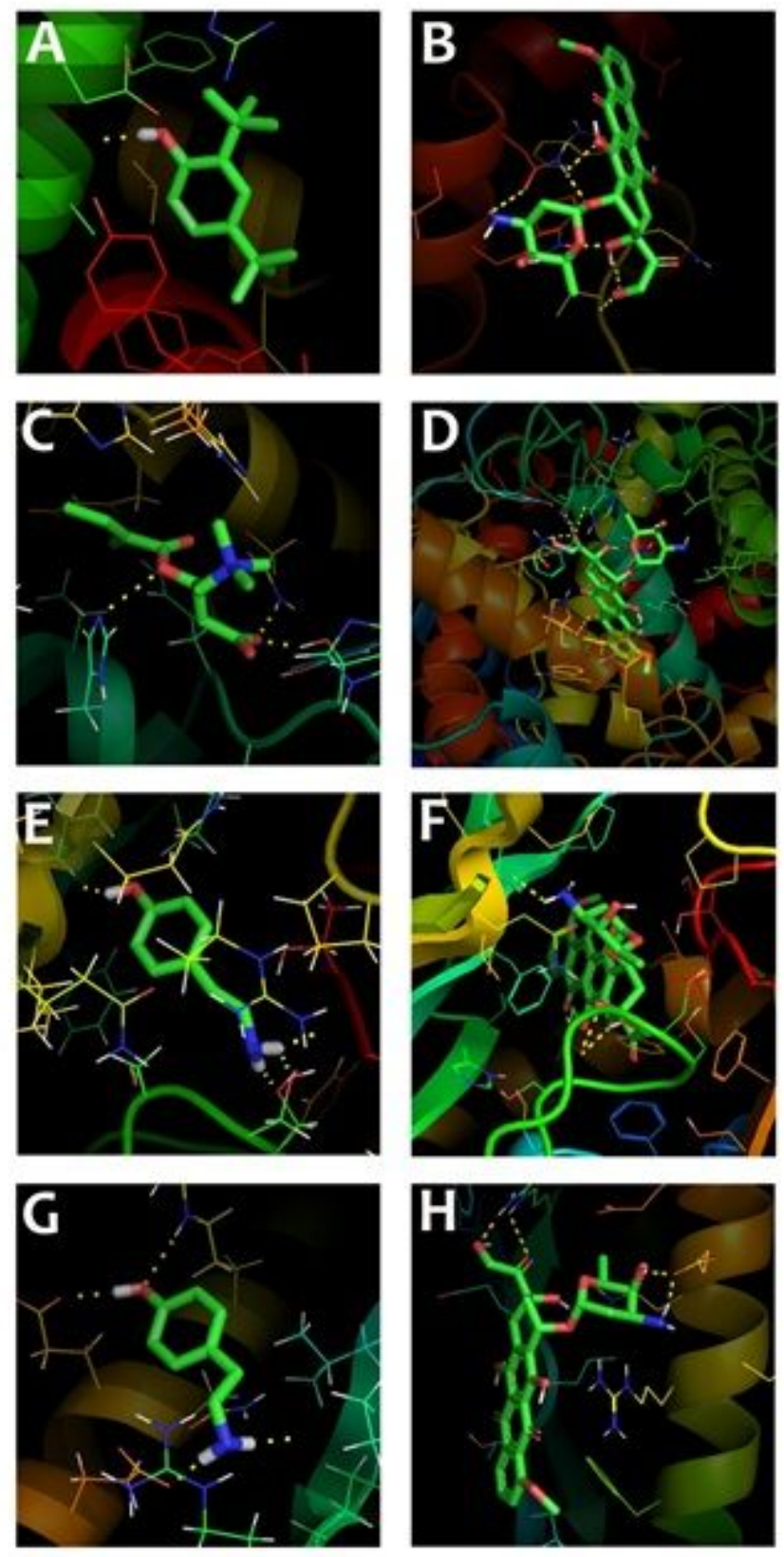

\section{Figure 5}

Binding modes of the compounds with the respective targets. A) Compound 22833596 with COX2, B) Doxorubicin with COX2, C)Compound 7311 with BCL2 D) Doxorubicin with BCL2, E) Compound 5610 with NAT2, F) Doxorubicin with NAT2, G) Compound 5610 with p53 and H) Doxorubicin with p53. In ligands, green color represents carbon atoms, blue for nitrogen, red for oxygen and white color for hydrogen. Yellow dotted lines represent the hydrogen bonds between the ligands and the targets 